\title{
A Study of Job Satisfaction of Secondary School Administrators in Kano State, Nigeria
}

\author{
Adebola O. Jaiyeoba \& Jibril, Mukhtari Ado
}

\begin{abstract}
This paper was concerned with studying the job satisfaction of secondary school administrators in Kano state, Nigeria. Survey design was used and a random sampling was used to select the study sample of 421 subjects used for the study. The Job Descriptive Index was used to collect data. Five hypotheses were raised in the study and the data collected was analysed using t-test and analysis of variance (ANOVA). Findings of the study showed that there was no significant difference in male and female; public and private; rural and urban administrators' level of job satisfaction. Also, the study found that there was a significant difference in the level of satisfaction with years of experience as well as with age, marital status, school size and educational qualification.
\end{abstract}

\section{Introduction}

The practices of teachers are a very vital function in the educational development of any nation and society. Teachers are seen as a group of key and vital body of professionals for a nation's development. School administrators, despite the title are teachers. They work in a condition that their job satisfaction matters a lot. People vary in their needs in the work place. The extent to which the school administrators are satisfied with their job is a potential indicator of their commitment to their responsibilities, managerial effectiveness and motivation. If there is a poor relationship between and among persons, environment and job characteristics, there may be problems with their behaviour at work.

The Nigerian National Policy on Education (NPE, 2004) was succinctly clear on the need and importance of a well motivate 
teaching force, but was also very clear on the role and functions of school administration and the vital function that the school administrators will play in the overall achievement of the national goals via education. A lot is expected of them in respect of bringing about the effectiveness of the system in all the thirty- six states of the Nigerian federation, Kano State inclusive. Their functions and roles are so varied in both content and context. The school system like all formal organizations has specific administrative tasks and functions to perform or execute. They are required to perform these stated roles and functions despite multifarious problems and challenges that are abound in the performance of these functions.

In the field of management, several scholars, starting from the Scientific Management theorists like Fredrick Taylor and Henri Fayol, through the Human Relationists like Elton Mayo, Mary Parker Follet and Roethlisberger, to the Behaviourist like Urwick, Gullick and Barnard have attempted to define what these functions are. In the same vein, number of works, studies and government documents (e.g. Hoyle, 1989; Musaazi, 1985; Gorton, 1983; \& The Kano State Ministry of Education, 1982), had gone a long way to spell out these expected roles, functions and duties of the school administrator.

These roles and functions of the school administrator are broad in their scope, nature as well as the extent of linkages in them. The school administrators in all ramifications are expected to function within the defined network of relationships in order to strive to attain the much- desired success in their schools. This does not however preclude the possibility of problems, challenges and other obstacles that may mar the effective functioning of the school administrators.

The two terms motivation and job satisfaction are very important and of major concern in all organizations, educational organizations inclusive. The two concept are however not easy to define easily and satisfactorily. Often, they are interchangeably used to mean that a motivated worker is a satisfied worker, or a satisfied worker is a motivated worker. 
Job satisfaction is a nebulous concept: people, workers and administrators as well as managers talk about it a great deal, but if pressed to explain exactly what they mean are hard pushed to provide a precise definition. The concept (Mumford, 1999) can be freely translated as an individual liking more aspects his work than he dislikes. Vroom (1964) described the concept as the positive orientation of an individual towards work role, which he is presently occupying. It has also been described as feelings about various aspects of the workers work setting (Hellreigel \& Slocam, 1976). The term job satisfaction and job attitude are used interchangeably. Both refer to effective orientations on the part of individuals towards work roles they occupy. Positive attitudes towards the job are conceptually equivalent to job satisfaction and negative attitudes to the job are equivalent to job dissatisfaction (Vroom, 1964).

Lock (1976) provided a comprehensive definition of the term as a pleasurable or positive emotional state resulting from the appraisal of one's job or job experience. Mitchell \& Larson (1987) saw job satisfaction as the result of employees' perception of how well their job provided those things, which are viewed as important. It is generally recognize in the field of organizational behaviour that job satisfaction is the most important and frequently studied attitude.

Several theories had been brought forward to explain job satisfaction. Some of these theories are also theories of motivation. This is so as writers pointed to the fact that the two concepts are tied together, and it is very difficult to draw a divide line between them (Peretemode, 1991). Therefore the numerous theories that explain job satisfaction could be categorized as content theories, process theories or integrative model.

The success or failure of the education industry largely depends on satisfied teachers and of course satisfied school managers and administrators. This is the concern of policy makers and also of interest to researchers. Several studies had been carried out on job satisfaction among school teachers and school administrators'. The 
interest in these studies lays in the fact that the performance of the educational system hinges on the performance of those concerned with its daily run. The educational system will therefore not be performing smoothly and effectively when the school managers and administrators are satisfied.

Some of these studies, for instance, Ogunsanya, (1981); Ajayi, (1981); Ikhioya, (1989); Adeyemo,(2001); Adeniji, (2001); \& Eshete, (2004) were concerned with the job satisfaction of teachers. While others for example, Ashton, (1989); Gentry, (1994); Hardman (1996) \& Thornton,(1996); where specifically concerned with various facets and aspects of job satisfaction among school administrators.

\section{Problem of the study}

The education enterprise or industry, like any other, is very much dependent for its success on the management and administrators that oversee its day- to- day operations. Their motivational state and the level of their satisfaction on the job are of definite concern. Kano state is the most populous state in Nigeria. In Kano State alone, there are more than five hundred public and private secondary schools with hundreds of thousands of students and teachers in these schools. Studying the fact that whether these school administrators in Kano State, by their various profiles are satisfied with their jobs is quite relevant.

\section{Hypotheses}

In the light of the foregoing this study sets out to test the following hypotheses, that:

1) There is no significant difference between male and female school administrators' level of job satisfaction.

2) There is no significant difference between private and public school administrators' level of job satisfaction.

3) There is no significant difference between urban and rural school administrators' level of job satisfaction. 
4) There is no significant difference between years of experience and the levels of job satisfaction of the school administrators.

5) There is no significant relationship between school administrators' marital statuses, age, school size, and educational qualification and their level of job satisfaction.

\section{Methodology}

The design for the study was a descriptive survey, as it is concerned with determining and describing the job satisfaction of school administrators in Kano State, Nigeria. The subjects for the study therefore consisted of 183 randomly selected schools (150 public and 55 private). The total number of respondents was 429 school administrators, which are principals and vice-principals. The Stratified random sampling technique was used to select the sample. The data for the study was collected using the Job Descriptive Index (JID); a standardized instrument, adapted from Smith, Kendall \& Hulin (Synder \&Dietrich III, 1992). The index consisted of five facets/factors (Work itself, Pay, Promotion, Supervision, and Coworkers). The instrument was modified from its original form. After its modification, it was vetted again for face validity after which adjustment where made before its reliability was determined using the test-retest method and a correlation coefficient(r) obtained was 0.83 , which indicated a high degree of reliability. The respondents where requested to rate the items on the questionnaire on a 4-point rating scale from "'Strongly Agree" (4 points) to "Strongly Disagree" (1 point). A total of 429 questionnaires were distributed for the purpose of data collection. A total of 342 completed questionnaires were returned and all were found useful.

\section{Data Analysis and Results}

The data was analysed using t-Test and Analysis of Variance (ANOVA) to determine the differences between the means. Simple percentage was also used to analyze some of the data that was collected. The analysis and results of findings are given in the following tables according to hypotheses tested: 
Hypothesis 1: There is no significant difference between male and female school administrators' level of job satisfaction.

Table 1 shows that the mean score of the female administrators is slightly higher than that of the male. Also, the calculated t-value (0.44) is lesser than the critical-t value (1.96), which shows that there was no significant difference between the two groups. We therefore accept the hypothesis that there is no significant difference between male and female school administrators' level of job satisfaction

Hypothesis 2: There is no significant difference between private and public school administrators' level of job satisfaction.

Table 2 shows the mean score for private school administrators' job satisfaction is higher than that of public school administrators. It can also be seen that, the value of t-calculated is less than the critical-t value, thus implying that no significant difference exists in the level of job satisfaction the two groups. By this therefore, we accept our hypothesis that there is no significant difference in their level of job satisfaction.

Hypothesis 3: There is no significant difference between urban and rural school administrators' level of job satisfaction.

From table 3 below it can be observed that the mean score of the urban school administrators is slightly higher than that of the rural school administrators. From the same table, one can also see that the calculated $t$-value $(0.50)$ is lower than the critical-t value of 1.96 . Thus revealing that no significant difference between the groups. By this therefore, the hypothesis is accepted.

Hypothesis 4: There is no significant difference between years of experience and the level of job satisfaction of the school administrators.

From table 4 below, it can be observed that the F-value is 4.10; the table value of $\mathrm{F}$ at 2,339 degrees of freedom at the 0.05 level of 
significance is 3.00 . Therefore, since the calculated $-\mathrm{F}$ value $(\mathrm{F}=4.10)$ is greater than the tabulated $-\mathrm{F}$ value $[\mathrm{F}=(0.4)=3.00]$, it is assumed that a significant difference exists between the groups. Hence the hypothesis is rejected.

Hypothesis 5: There is no significant relationship between school administrators' marital statuses, age, school size, and educational qualification and their level of job satisfaction.

Table 5 shows that $\mathrm{F}$-value is 2.25 . The table value of $\mathrm{F}$ at 8,333 degrees of freedom at the 0.05 level of significance is 3.00 . Therefore, since the F-value $(\mathrm{F}=2.25)$ is less than the table-F value $[\mathrm{F}=(.05)=3.00]$, it is assumed that on the whole there is no significant difference the between variables. It could however be seen from the table that there is a significant difference in job satisfaction with School Size and Educational Qualification. This is evident in the fvalues yielded by the variables (School Size $=3.81$ and Educational Qualification= 5.39). The other variables indicated that no significant difference exists in the level of job satisfaction with the rest of the variables. This can be seen from the F-values yielded by the variables. This can also be seen by the f-values yielded by the variables (Marital Status=1.06 and Age =.77). The hypothesis is therefore rejected. Not accepted.

\section{Discussions}

The main focus of this study was to study the job satisfaction of school administrators in Kano state considering their various personal profiles. The study established that there is no significant difference between male and female school administrators' level of job satisfaction. This finding agrees with the findings of other studies. Thornton (1996) found that there was no significant difference between the job satisfaction of male and female assistant principals. Also, Hardman (1996) found that females in administrative positions in West Virginia public school system had a high level of job satisfaction. The data in this study also showed that females have a higher level of satisfaction than their male counterparts. Gentry (1994) 
reported moderate to high levels of job satisfaction among principals. Thus re-echoing what has been established by this study. Several factors within and outside the work setting could be seen as responsible for the reported high level of satisfaction by the respondents. For example, family members, colleagues and so forth can bring about lots of encouragement and support to make them feel what they are doing is not in vain.

The results also showed that there is no significant difference between public and private school administrators' level of job satisfaction. The mean scores for the two groups as indicated table 2 are high, meaning that there is a high level of job satisfaction in the group. This finding has been supported by other studies on school principals and assistant principals, e.g. Ashton (1989); Gentry (1991); \& Thornton (1996). These studies found moderate to high levels of satisfaction among their subjects.

It could be seen from the findings of this study that both public and private school administrators are satisfied with the five facets of the job descriptive index of work itself, pay, promotion, supervision, and co-workers. The fact that no significant difference exists between the two groups, point to the fact that, both are essentially performing similar functions if not same functions with about the same level of commitment. They essentially strive to about same or similar goals and objectives in about the same way. The difference between them is perhaps in terms of resources, difference inputs (students), and in different environments. Performing their functions it appears gives them joy and pleasure despite what many may view as the job of a school head being not a good paying job with poor social image, poor prospects in promotions and other available opportunities.

Similarly, data analysis indicated that there was no significant difference between the level of satisfaction of urban and rural school administrators. Although there is no study that had a direct relevance to buttress this, some studies (Frick, 1989 \& Burke, 1995) had however reported rural county elementary school teachers are satisfied 
with their work. This study indicated that variations in environmental settings and some of the advantages that urban life could bring over rural life do not bring about differences in satisfaction. What may matter most may certainly be that the school administrators despite their school locations see themselves as professionals who have a career, calling and a duty to perform to their society wherever they find themselves. They see themselves as role models, umpires and sources of support to their students and the local community. In view of this, one might not be surprised at the high level of satisfaction. This assertion was partly supported in a study (Frick, 1989) of rural teachers. The study showed that rural teachers were satisfied with teaching as career and feel that they where role models for their children.

From the analysis of the data collected, a significant difference was obtained between years of experience and the level of job satisfaction of the school administrators. Although no study was found by the researcher that supported this finding, there should however be an explanation. It has been shown in several studies that individual needs, relationships, support and perhaps some extent self perception, to a large extent determine an individual's job satisfaction. So it could be posited that, school administrators who had few years of work experience, have an insatiable need to excel and attain the pinnacle of their careers. The drive in them propels them to immerse themselves whole-heartedly into their work. In effect they get married to their jobs. Whereas the more experienced ones have put in a lot of their lives into the job, they may not have much zeal and higher attainment needs and perhaps energy. In fact most of them may be in their menopause stage at work, and they are only marking time. Perhaps they are even tired, from the context of the job. Their superiors are their peers, mates or even juniors in the service. This will in no small measure affect their job satisfaction.

The analysis of data also showed that there is a significant relationship among school administrators' marital status, age, school size, and educational qualification and their level of job satisfaction. This 
finding supports the previous findings of Hardman (1996). He found a statistically significant relationship with regards to age, years of educational qualification, and marital status. In relation to school size, other studies, e.g., Thornton (1996) found that there was a significant relationship between assistant principals' job satisfaction and school size.

\section{Conclusions and Implications}

This paper was concerned with studying the job satisfaction of school administrators in Kano state, Nigeria. Five hypotheses were raised to guide the study. Three of these were accepted. Thus, no significant difference in the satisfaction of the school administrators' level of satisfaction, in respect of, gender, school type or ownership and the school setting. The two hypotheses rejected showed that there was a significant difference found between the school administrators' level of satisfaction with years of experience and with their age; marital status; school size and educational qualification. The implications of these findings are that there exists a high level of reported job satisfaction in the sampled group. This can be seen as a serious challenge for policy makers in the state and for the various private school boards to seek to find newer and more effective ways of motivating and ensuring a sustained level of job satisfaction in the school administrators; at the same time, also find ways of determining how to bridge the obtained differences in satisfaction levels of the study group. 


\section{References}

Adeniji , A. (2001). "Job Satisfaction among Secondary School Teachers in Abeokuta Metropolis." African Journal of Educational Management Vol. 9 No.1

Adeyemo, D. A. (2001). "A Test of Multiplicative Effects of Job and Life Satisfaction on the Career Commitment of Secondary School Teachers in Oyo state, Nigeria." African Journal of Educational Management Vol. 9 No.1

Ashton, F.L. (1989). "Connecticut Middle School Principals' Job Satisfaction with Regards to Selected Motivators and Hygiene". Unpublished $\mathrm{PhD}$ Thesis, Dissertations Abstracts International. Vol. 50, No.11

Burke, S. M. (1995). "Job Satisfaction of Elementary Teachers in Alberta Country Schools." Unpublished D.Ed Thesis, Dissertations, Abstracts International, Vol. 58, No.9

Eshete, A. (2004). "Job Satisfaction and its Implication to Secondary Teacher Management Policy." IER FLAMBUE Vol. 12 No. 1

Frick, J. K .(1989). "Factors Related to Rural Teachers' Satisfaction with Teaching, Career Longevity, and Desire to Remain in Teaching." Unpublished PhD Thesis, Dissertations, Abstract International. Vol.50, No.11

Gentry, L.R.S. (1994). "The Relationship between Job Satisfaction and Social Network Characteristics of Elementary School Principals. Unpublished D. Ed. Thesis ,Dissertations, Abstract International Vol.56, No. 1

Gorton, R. A. (1983). School Administration and Supervision: Leadership Challenges and Opportunities. New York: Harper Row Publishers.

Hardman, T. R. (1996). "A Study of Job Satisfaction and Organizational Factors for Differential Environmental Context and Career Stages." Unpublished PhD Thesis, Dissertations, Abstract International. Vol. 57, No.12.

Hellreigel, D. \& Slocam, J. (1976). Organizational Behaviour; Contingency Views. New York: West Publishing Co.

Hoyle, E. (1989). "The Study of Schools as Organizations." Vincent, H., Royson, M., \& Colin, M. (Eds.) Management in Education: The Management of Organizations and Individuals._Ward Lock Educational/Open University Press.

Kano State Ministry of Education, (1982). Rules and Regulations for Post Primary Institutions. 
Lock , E. A.(1976). "The Nature and Cause of Job Satisfaction.” Dunnette, M. D. (Ed.), Handbook of Industrial and Organizational Psychology. Chicago: Rand McNally

Mitchell, R. H. \& Larson, H. (1987). Behaviour in Organizations. Boston: Allyn and Bacon

Mumford, E. (1999). "Job Satisfaction: A Method of Analysis." Personnel Review, Vol.20, No.3

Musaazi, J.C.S. (1985). The Theory and Practice of Educational Administration. Hong Kong: McMillan Publishers.

Ogunsanya, M. (1981). "Teacher Job Satisfaction and Productivity as Factors of Academic goal Achievement in Oyo State Secondary Schools." Unpublished PhD Thesis, University of Ibadan.

Peretemode, V. F. (1991). Educational Administration; Applied Concepts and Theoretical Perspectives for Students and Practitioners. Lagos: Joja Press

Synder, R. A. \& Dietrich III, F. H. (1992). Age/Job Satisfaction Assessment of the Shape of the Relationship from a Systems Perspective

Thornton, C. L. (1996). "Job Satisfaction and the Assistant Principalship in Central Florida School District" Unpublished PhD Thesis. Dissertations Abstract International, Vol. 57, No.7

Vroom, V. (1964). Work and Motivation. New York: Wiley 
Table 1: Male and Female School Administrators' Job Satisfaction

\begin{tabular}{|l|l|l|l|l|l|l|l|l|}
\hline Variables & $\mathrm{N}$ & Mean & S.D & $\begin{array}{l}\text { Std. } \\
\text { Err }\end{array}$ & t-cal & Tab-t & Df & Sig. \\
\hline Male & 218 & 164.42 & 18.88 & 1.27 & 0.44 & 1.96 & 340 & 0.66 \\
\hline Female & 124 & 165.36 & 19.43 & 1.74 & & & & \\
\hline
\end{tabular}

Table 2: Level of Job Satisfaction of Public and Private School Administrator Job Satisfaction

\begin{tabular}{|c|l|l|l|l|l|l|l|l|}
\hline Variables & $\mathrm{N}$ & Mean & S.D & Std. Err & t-cal & Tab-t & Df & Sig. \\
\hline Public & 269 & 163.94 & 19.26 & 1.77 & 1.53 & 1.96 & 340 & 0.12 \\
& & & & & & & & \\
\hline Private & 73 & 167.78 & 18.13 & 2.12 & & & & \\
& & & & & & & & \\
\hline
\end{tabular}

Table 3: Urban and Rural School Administrators' level Job Satisfaction

\begin{tabular}{|l|l|l|l|l|l|l|l|l|}
\hline Variables & $\mathrm{N}$ & Mean & S.D & Std. Err & t-cal & Tab-t & Df & Sig. \\
\hline Urban & 226 & 165.13 & 19.16 & 1.27 & 0.50 & 1.96 & 340 & 0.62 \\
& & & & & & & & \\
\hline Rural & 116 & 164.05 & 18.92 & 1.75 & & & & \\
\hline
\end{tabular}


Table 4: Analysis of Variance Showing Job Satisfaction by Experience

\begin{tabular}{|l|l|l|l|l|l|}
\hline $\begin{array}{l}\text { Source of } \\
\text { variation }\end{array}$ & $\begin{array}{l}\text { Sum of } \\
\text { Squares }\end{array}$ & df & $\begin{array}{l}\text { Mean } \\
\text { Square }\end{array}$ & F & Sig. \\
\hline $\begin{array}{l}\text { Main Effects } \\
\text { (experience) }\end{array}$ & 2929.48 & 2 & 1464.74 & 4.10 & 0.17 \\
\hline Explained & 2929.48 & 2 & 1464.74 & 4.10 & 0.17 \\
\hline Residual & 120995.78 & 339 & & & \\
\hline Total & 123925.28 & 341 & & & \\
\hline
\end{tabular}

Table 5: Analysis of Variance showing Job Satisfaction by Marital Status, Age, School Size and Qualification

\begin{tabular}{|l|l|l|l|l|l|}
\hline $\begin{array}{l}\text { Source of } \\
\text { variation }\end{array}$ & $\begin{array}{l}\text { Sum of } \\
\text { Squares }\end{array}$ & Df & $\begin{array}{l}\text { Mean } \\
\text { Square }\end{array}$ & F & Sig. \\
\hline Main Effects & 6367.40 & 8 & 795.92 & 2.25 & .02 \\
\hline Marital Status & 752.65 & 2 & 376.82 & 1.06 & .34 \\
\hline Age & 823.82 & 3 & 274.60 & .77 & .50 \\
\hline School Size & 2694.08 & 2 & 1347.04 & 3.81 & .02 \\
\hline $\begin{array}{l}\text { Educational } \\
\text { Qualification }\end{array}$ & 2095.84 & 1 & 2095.84 & 5.93 & .01 \\
\hline Explained & 6367.40 & 8 & 795.92 & 2.25 & .02 \\
\hline Residual & 117557.87 & 333 & 353.02 & & \\
\hline Total & 123925.28 & 341 & 363.41 & & \\
\hline
\end{tabular}

